\section{New factor released by cultured glioma cells supporting survival and growth of sensory neurones}

PROCESS formation can be induced in clonal neuroblastoma cells by a macromolecule termed glial factor which has been identified in medium conditioned by cultured C- 6 glioma cells ${ }^{1}$. Fibre outgrowth can also be elicited in cultures of peripheral sensory neurones ${ }^{2}$ by the well-characterised mouse submaxillary gland nerve growth factor $(\mathrm{NGF})^{3}$, which has been shown to be a different entity from glial factor ${ }^{4}$. We report here that glioma-conditioned medium (GCM), the source of glial factor, can support both survival and fibre formation of isolated chick sensory neurones and that neither NGF nor glial factor are responsible for this effect.
We conclude that C-6 glioma cells release into the culture medium a substance, probably a polypeptide, which can support the survival and process formation of dissociated neurones from chick embryo sensory ganglia. This substance is neither NGF nor the previously described glial factor ${ }^{1}$. Hitherto NGF has been the only factor known to have the ability to support the survival of peripheral sensory neurones during a critical phase of their development. The existence of a factor other than NGF with this property means that in this respect at least NGF can no longer be considered unique.

Table 1 Comparison between the effects of NGF and GCM on the survival of chick sensory neurones

\begin{tabular}{|c|c|c|c|c|c|c|}
\hline \multirow[t]{2}{*}{$a$} & Control & $\mathrm{NGF}\left(1 \mathrm{ng} / \mathrm{ml}^{-1}\right)$ & $\begin{array}{l}\text { NGF }\left(1 \mathrm{ng} \mathrm{ml}^{-1}\right) \\
\quad+\mathrm{Ab}\left(100 \mathrm{ng} \mathrm{ml}^{-1}\right)\end{array}$ & $\mathrm{GCM}$ & \multicolumn{2}{|c|}{$\mathrm{GCM}+\mathrm{Ab}\left(100 \mathrm{ng} \mathrm{ml}^{-1}\right)$} \\
\hline & $300 \pm 150$ & $2,500 \pm 700$ & $350 \pm 150$ & $1,300 \pm 300$ & $1,350 \pm 250$ & \\
\hline \multirow[t]{2}{*}{$b$} & Control & $\operatorname{NGF}\left(1 \mathrm{ng} \mathrm{ml}^{-1}\right)$ & GCM & $\mathrm{GCM}+\mathrm{Ab}\left(10 \mu \mathrm{g} \mathrm{ml}^{-1}\right)$ & GCM + Pronase & $\begin{array}{l}\text { Inact. Pronase } \\
\quad+\text { NGF }\left(1 \mathrm{ng} \mathrm{ml}^{-1}\right)\end{array}$ \\
\hline & $950 \pm 200$ & $5,250 \pm 350$ & $3,950 \pm 500$ & $4,500 \pm 650$ & $1,950 \pm 300$ & $4,250 \pm 850$ \\
\hline
\end{tabular}

The results in $a$ and $b$ are from two separate experiments. Cell numbers shown are the mean of triplicate determinations \pm s.d. and represent the total number of surviving neurones per $35-\mathrm{mm}$ dish. Nine per cent of the surface of the dish was counted. Cultures were prepared by adding $1.0 \mathrm{ml}$ of cell suspension (25,000-35,000 cells in F-14 medium) to $1.0 \mathrm{ml}$ of Dulbecco's modified Eagle's medium (DMEM) containing (where indicated) twice the final amount of NGF and/or NGF antibodies (Ab). Both F-14 and DMEM contained $5 \%(v / v)$ fetal calf serum and $2 \%(v / v)$ chicken serum (Gibco). On testing GCM, it was substituted for an equivalent volume of DMEM. GCM was obtained by culturing C-6 glioma cells as described

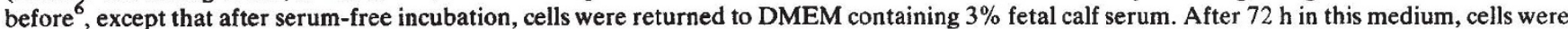
again cultured in serum-free medium for three consecutive $24-\mathrm{h}$ periods. The conditioned medium obtained during the last period was the most active and was used in the experiments. At that time, the glioma cells had reached a density of $9 \times 10^{8}$ per roller flask and the protein concentration of the conditioned medium was $10-20 \mathrm{\mu g} \mathrm{ml}^{-1}$. The GCM was centrifuged and used without filtration. NGF was purified essentially according to Bocchini and Angeletti ${ }^{7}$. Maximal fibre outgrowth was produced in the chick dorsal root bioassay at a concentration of 5-10 $\mathrm{ng} \mathrm{ml}^{-1}$ (ref. 8). Antibodies were purified by passing the NGF-antiserum over an NGF-Sepharose column as previously described ${ }^{9}$. In $b$, GCM was exposed to Pronase (Serva) $\left(10 \mu \mathrm{g} \mathrm{ml}^{-1}, 30 \mathrm{~min}, 37^{\circ} \mathrm{C}\right)$ and subsequently heated for $30 \mathrm{~min}$ at $60^{\circ} \mathrm{C}$. Such heat treatment did not reduce the activity of GCM but did inactivate the Pronase, as shown. DMEM was similarly treated (Pronase followed by heat inactivation) before the addition of NGF. The number of surviving neurones is not different from that for DMEM+NGF untreated control.

Dorsal root ganglia from 10-12-d-old chick embryos were dissociated and plated on collagen-coated dishes, after a preplating period to eliminate most non-neuronal cells as before ${ }^{5}$. Surviving neurones (defined as process-bearing cells with highly refractile soma) were counted after $48 \mathrm{~h}$. In the absence of either NGF or GCM, less than $5 \%$ of the cells plated survived. The addition of either GCM or NGF led to a marked increase in the number of surviving neurones. As Table 1 shows, the effect of NGF could be abolished by specific antibodies to NGF. In contrast, the increased survival of neurones promoted by GCM was not blocked by the NGF antibodies, even when the concentration of antibody used was 100 times greater than that required to block the effect of NGF (Table $1 b$ ).

Partially purified glial factor (eluted as a single peak from a DEAE-cellulose column, R.M.L. and D.M., unpublished results) did not support the growth of the isolated sensory neurones in spite of an increase in specific activity of more than 80 -fold as determined by neuroblastoma bioassay. Therefore we conclude that the support of survival and the induction of fibre outgrowth in sensory neurones were due to a factor other than that responsible for neuroblastoma cell process formation, that is, something other than glial factor.

Digestion of GCM with Pronase markedly reduced the ability of GCM to support the survival of sensory neurones (Table $1 b$ ). Similar results were obtained after digestion with $\alpha$-chymotrypsin, suggesting that this factor might be a polypeptide. Further characterisation is in progress.

\author{
Y. A. BARDE* \\ R. M. LINDSAY†‡ \\ D. MONARD ${ }^{\dagger}$ \\ H. THOENEN*
}

* Department of Pharmacology,

Biozentrum der Universität,

Klingelbergstrasse $70 \mathrm{CH}-4056 \mathrm{Basel}$, Switzerland

†Friedrich Miescher Institut,

Postfach 273, CH-4002 Basel, Switzerland

Received 24 April; accepted 20 June 1978.

‡ Present address: Laboratory of Neurobiology, National Institute for Medical Research, Mill Hill, London NW7, UK.

1. Monard. D., Solomon, F., Rentsch, M. \& Gysin, R. Proc. natn. Acad. Sci. U.S.A. 70, 1894-1897 (1973).

2. Levi-Montalcini, R. \& Angeletti, P. U. Devl Biol. 7, 653-659 (1963). Mobley, W. C., Server, A. C., Ishii, D. N., Riopelle, R. J. \&

4. Monard, D., Stöckel, K., Goodman, R. \& Thoenen, H. Nature 258, 444-445 (1975).

5. Greene, L. A. Devl Biol. 58, 106-113 (1977).

6. Monard, D., Rentsch, M., Schuerch-Rathgeb, Y. \& Lindsay, R. M. Proc. natn. Acad. Sci. U.S.A. 74, 3893-3897 (1977).

7. Bocchini, V. \& Angeletti, P. U. Proc. natn. Acad. Sci. U.S.A. 64, 787-794 (1964).

8. Fenton, E. L. Expl Cell Res. 59, 383-392 (1970).

9. Stöckel, K., Gagnon, C., Guroff, G. \& Thoenen, H. J. Neurochem. 26, 1207-1211 (1976). 